\title{
A COMPARISON OF THE EFFECTIVENESS OF LCD PROJECTOR AND CHALKBOARD AS A TEACHING AID FOR UNDERGRADUATE LECTURE CLASSES
}

\author{
Mary Chacko P1
}

${ }^{1}$ Professor, Department of Physiology, Government Medical College, Thiruvananthapuram.

ABSTRACT
BACKGROUND
LCD projector is an AV aid with versatile uses, but frequent power failure and lack of availability of the equipment, has led to
considering cheaper and easily available alternatives like chalkboard. The present study was conducted among first year medical
students of Government Medical College, Thiruvananthapuram to compare the effectiveness of LCD projector and chalkboard as a
teaching aid for undergraduate lecture classes.

\section{MATERIALS AND METHODS}

Interventional study design was chosen. 183 students who were willing to participate and have given written consent for the study were included. Lecture classes were taken using LCD projector as the only teaching aid. Class of similar difficulty was taken for the same batch using chalkboard. At the end of each class, separate MCQ tests were conducted and the marks of 183 students were compared. After the sessions were over feedback was given by 144 students. Data analysis was done using SPSS 21 . Mean scores of MCQ tests by the two methods were compared using unpaired t test. Feedback from the students was analysed using Chi square test.

\section{RESULTS}

The difference in the mean scores of MCQ tests was very highly significant, favouring the LCD projector. The feedback also favoured the LCD projector, especially for demonstration of diagrams and charts. The overall assessment also was similar for LCD projector and chalkboard.

\section{CONCLUSION}

In the present study, the LCD projector was preferred over the chalkboard as a teaching aid, especially for demonstration of diagrams and charts and the mean scores of MCQ tests. Other aspects of the two sessions were not significantly affected by the audio-visual aid used.

\section{KEYWORDS}

Comparison, LCD Projector, Chalkboard, Undergraduate, Lecture Classes.

HOW TO CITE THIS ARTICLE: Chacko MP. A comparison of the effectiveness of LCD projector and chalkboard as a teaching aid for undergraduate lecture classes. J. Evolution Med. Dent. Sci. 2017;6(60):4392-4397, DOI: 10.14260/Jemds/2017/950

\section{BACKGROUND}

The ability of every teacher to reach the students depends on the teaching style, the way they present information to students. It is wise to choose from a variety of teaching aids according to one's own ability and skills to handle them. A teaching aid is something which makes teaching easier for the teacher and makes learning more effective and enjoyable for the student. The chalkboard is one of the important aids used in teaching and perhaps the most popular and widely used visual aid. It is cheaper, commonly available and easy to maintain over long years. The chalkboard is only a smooth hard panel, usually green or black for writing on with chalk. Teacher can present content in the chalkboard to unfold naturally. The teacher can illustrate the main points of the lesson and questions on the board. This thing helps students

Financial or Other, Competing Interest: None.

Submission 21-06-2017, Peer Review 13-07-2017,

Acceptance 20-07-2017, Published 27-07-2017.

Corresponding Author:

Dr. Mary Chacko P,

Professor,

Department of Physiology,

Government Medical College,

Kottayam- 696008.

E-mail: marychacko5@gmail.com

DOI: $10.14260 /$ jemds $/ 2017 / 950$ follow, understand, and take note to remember longer and deeper. Also, the teacher can stick pictures, objects, maps and other items on the chalkboard to make the diversity in the lesson. ${ }^{1}$

Every teacher knows that there is a place for the chalk and board in the class room and every good teacher knows that it is not the only teaching aid. According to J Tomlinson, there are three types of teaching - regurgitating information word by word from text books and lesson plans, projecting using power points and using creative methods where the teacher uses a range of teaching aids to engage students. He is of the opinion that chalkboard is of no less importance than other technologically developed tools. He further adds that some high-tech facilities also can serve the same function as chalkboard such as interactive white board and the touch screen board. ${ }^{2}$

Ashley Brown ${ }^{3}$ states in her article that gone are the days when slide-show presentations with attention-grabbing graphics were the classroom's technological zenith. We live in the age where blogs, chat rooms and podcasts are common teaching tools. Yet a classroom can still thrive when stripped down to the basics -- chalk and a chalkboard. She states the advantages of chalkboards in teaching that it improves the following: 


\section{Teaching Effectiveness}

Writing on a chalkboard makes it easier to control the pace of a lecture because it encourages writing while talking. According to Barbara Gross Davis' book, "Tools for Teaching,"4 students need time to assimilate new information and to take notes, but if you speak too slowly, they may become bored. Try to vary the pace to suit your own style, your message and your audience.

\section{Classroom Management}

Disruptive students may be less disruptive if they are within a teacher's visibility which is assured in chalkboard instruction because it requires light. Students that see teachers construct diagrams on a chalkboard witness the process of turning written information into visual information. Teachers should emphasise the importance of this skill and its potential applications.

\section{Student Academic Success}

Writing information on a chalkboard helps teachers take visible cues from students. Teachers can immediately address students' body language and facial expressions that suggest confusion about the material. Teaching with chalk is especially an advantage for teachers of students with mixed learning abilities.

\section{Student Involvement}

Getting students to participate makes class more enjoyable for teacher and students alike.

In an article "Chalkboard and teacher as teaching aids" Nguyen Mai Xuyen has listed the various ways in which the chalkboard can be used as a teaching aid 5 for warm up activities and brainstorming, both formally prepared lessons or informal spontaneous sessions, to illustrate/draw diagrams and highlight using colour chalks, to illustrate procedures or the main topic of the lesson, to present the key words and new words, to list questions and problems in stepwise fashion, for graphs, graphics, sketches, maps and statistics, etc., as a wall where teachers and students can hang poster, pictures, draw diagram, map on to exhibit or show to other students or the teacher can stick flashcard, objects, pictures and handmade products, teacher can draw on the chalkboard to develop the topic, show part or build the association.

To assess the chalkboard skills of the teacher from the students' point of view, the following issues have to be considered 6 : Keep the board work as visible as possible. Give students time to take down what is written. Stop writing while analysing an idea. Keep the board work organised. If a mistake is made go back and make the correction. Maintain eye contact with your students.

The liquid crystal display (LCD) panel ${ }^{7}$ is designed to project on-screen information of a microcomputer onto a larger screen with the aid of a standard projector, so that large audiences may view it comfortably. Some advantages of the LCD panel include the flexibility of last minute text changes and less lead time needed for text preparation. It eliminates the problems of messy last-minute changes in, and improves legibility of handwritten overhead projector transparencies. In the hands of a teacher with appropriate skills it can be used for showing diagrams, charts, animations, flow charts and a lot many other things. The disadvantages of using an LCD panel include the relatively bulky equipment which may pose transport problems, equipment costs and power dependence. Barbara Davis gives tips on using the instrument effectively. ${ }^{4}$

According to Girish Kumar Ramaiah, ${ }^{8}$ it is doubtful whether the use of modern teaching aids has made the classrooms any better. He goes on to state that they have even reduced the originality of thinking and brain activity, quoting the calculator which has taken up even simple arithmetic calculations

Another article doubts whether the LCD projectors make chalkboards obsolete. ${ }^{9}$ The argument is that chalkboards are not good at conveying dynamic information. Software that is difficult to describe can be easily shown and many students are not auditory learners. The teacher is free to move about in class. The pictures have a better visual effect and are less confusing.

Runa M Borah ${ }^{10}$ in her article has described the various tips to use the modern teaching aids effectively. She concludes that any aid whether it is the chalkboard or the LCD projector, is only a teaching aid. It cannot substitute for a logical presentation of the material. Give the students a chance to deal with facts and concepts. Otherwise the students will be copying blindly without knowing where they are going.

The present study was aimed at making the best use of teaching aids in large group teaching methods. Lecture being the most commonly used method in this category, use of teaching aids in lecture classes was studied and the objective was to compare the effectiveness of the LCD Projector and the chalkboard as teaching aids for undergraduate lecture classes.

\section{MATERIALS AND METHODS}

\section{Study Design}

Intervention study design was chosen for the present study. The study design was non-randomised experimental study.

\section{Study Subjects \\ A single group of first year MBBS students.}

\section{Inclusion Criteria}

First year MBBS students who were willing to participate in the study and who have given written consent for taking part in the study.

\section{Exclusion Criteria}

Those who are absent in the class or are not willing and have not given written consent were not included in the study.

\section{Sample Size}

183 first year MBBS students.

\section{Study Setting}

The study was conducted in the Department of Physiology, Government Medical College, and Thiruvananthapuram over a period from January 2015 to March 2015.

\section{Methodology Proper}

Lecture classes were taken for a batch of first year MBBS students using LCD as the only AV aid. Classes of similar difficulty was taken for the same batch by the same teacher using chalkboard as the only teaching aid, so as to avoid teacher bias and student bias. At the end of each class, separate MCQ tests were conducted. Data analysis was done using SPSS 21. 
Mark sheets of 183 students who expressed willingness to take part in the study and gave written consent to this effect were taken for statistical analysis. Mean scores of MCQ tests after classes by the two methods were compared using unpaired $t$ test. (Post intervention).

After the sessions were over, feedback was given by 144 students. Feedback from the students was analysed using Chi-square test. The following points were included in the feedback form to be given scores separately each one independently, based on its merit.

- Introduction to topic.

- Understanding of subject matter.

- Flow of subject matter.

- Demonstration of diagrams.

- Demonstration of charts.

- Keeping eye contact with students.

- Conclusion.

- Overall assessment of the session.

Likert scale was used for scoring as follows:

Excellent - 5; Very good - 4; Good - 3; Average - 2; poor - 1 .

\section{RESULTS}

Marks of the MCQ tests conducted after each class was evaluated and the marks were tabulated. From this the mean value of the marks obtained for the two tests were calculated. These two were compared using unpaired t test.

\begin{tabular}{|c|c|c|c|c|c|}
\hline $\begin{array}{c}\text { T-L } \\
\text { Method }\end{array}$ & $\begin{array}{c}\text { No. of } \\
\text { Students }\end{array}$ & $\begin{array}{c}\text { Mean } \\
\text { Marks }\end{array}$ & $\begin{array}{c}\text { Statistical } \\
\text { Test }\end{array}$ & $\begin{array}{c}\text { t } \\
\text { Value }\end{array}$ & $\begin{array}{c}\text { Signi- } \\
\text { ficance }\end{array}$ \\
\hline $\begin{array}{c}\text { Lecture with } \\
\text { Chalkboard }\end{array}$ & 183 & 7.978 & $\begin{array}{c}\text { Unpaired t } \\
\text { test }\end{array}$ & 6.573 & 0.0001 \\
\hline $\begin{array}{c}\text { Lecture with } \\
\text { LCD }\end{array}$ & 183 & 9.005 & & & \\
\hline \multicolumn{7}{|c|}{ Table 1. Comparison of Mean Marks Scored by Students } \\
\hline
\end{tabular}

As observed from the results of statistical analysis, it is found that the marks obtained after the class using LCD as the teaching aid is greater than that after the class using chalkboard and the difference between the two values is statistically significant. Feedback forms were given to students after the sessions were over and their observations were analysed using the 8 parameters given in methodology and scored using a Likert scale from 5 to 0 .

Analysis of the feedback obtained from students gave the following observations which are represented graphically using bar diagrams and using tables as the exact percentage. Each parameter was analysed separately on its own merits and evaluated.

\section{Analysis of Feedback from Students}

Introduction to Topic

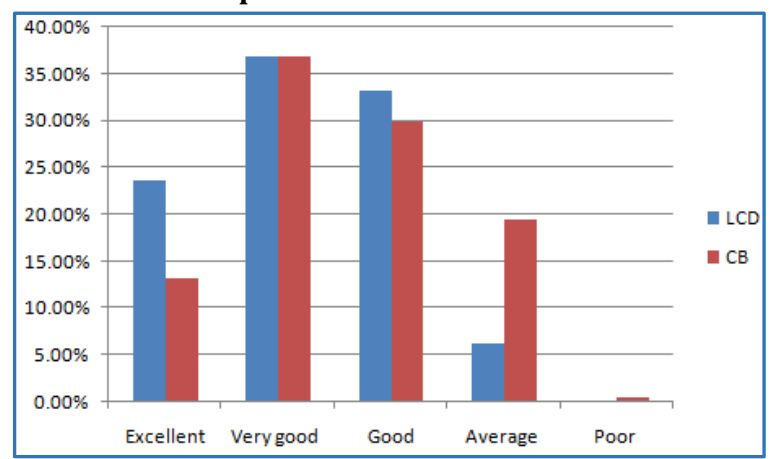

Bar Diagram 1

LCD- LCD Projector, CB- Chalkboard

\begin{tabular}{|c|c|c|}
\hline Teaching Aid used & LCD & Chalkboard \\
\hline Excellent & $23.60 \%$ & $13.20 \%$ \\
\hline Very good & $36.80 \%$ & $36.80 \%$ \\
\hline Good & $33.30 \%$ & $29.90 \%$ \\
\hline Average & $6.30 \%$ & $19.40 \%$ \\
\hline Poor & $0 \%$ & $0.60 \%$ \\
\hline Table 2. Introduction to Topic Percentage \\
Distribution of Feedback \\
\hline
\end{tabular}

\section{Understanding of Subject Matter}

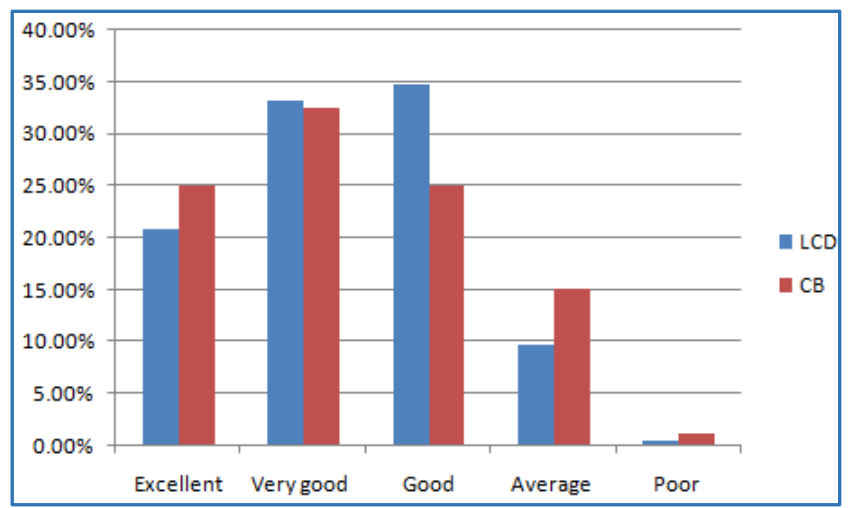

Bar Diagram 2

\begin{tabular}{|c|c|c|}
\hline Teaching Aid used & LCD & Chalkboard \\
\hline Excellent & $20.80 \%$ & $25.00 \%$ \\
\hline Very good & $33.30 \%$ & $32.60 \%$ \\
\hline Good & $34.70 \%$ & $25.00 \%$ \\
\hline Average & $9.70 \%$ & $15.20 \%$ \\
\hline Poor & $0.60 \%$ & $1.30 \%$ \\
\hline Table 3. Understanding of Subject Matter Percentage \\
Distribution of Feedback \\
\hline
\end{tabular}

\section{Flow of Subject Matter}

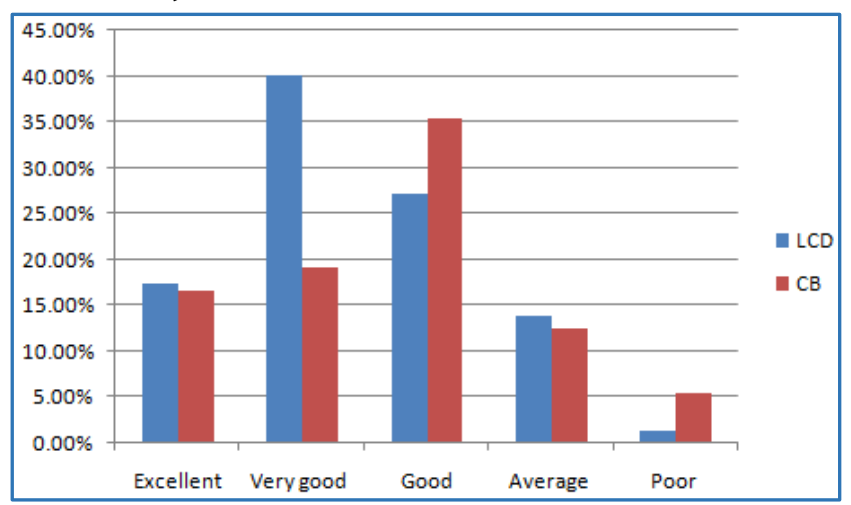

Bar Diagram 3

\begin{tabular}{|c|c|c|}
\hline Teaching Aid used & LCD & Chalkboard \\
\hline Excellent & $17.40 \%$ & $16.70 \%$ \\
\hline Very good & $40.20 \%$ & $19.20 \%$ \\
\hline Good & $27.10 \%$ & $35.40 \%$ \\
\hline Average & $13.80 \%$ & $12.50 \%$ \\
\hline Poor & $1.30 \%$ & $5.50 \%$ \\
\hline Table 4. Flow of Subject Matter Percentage Distribution of \\
Feedback \\
\hline
\end{tabular}




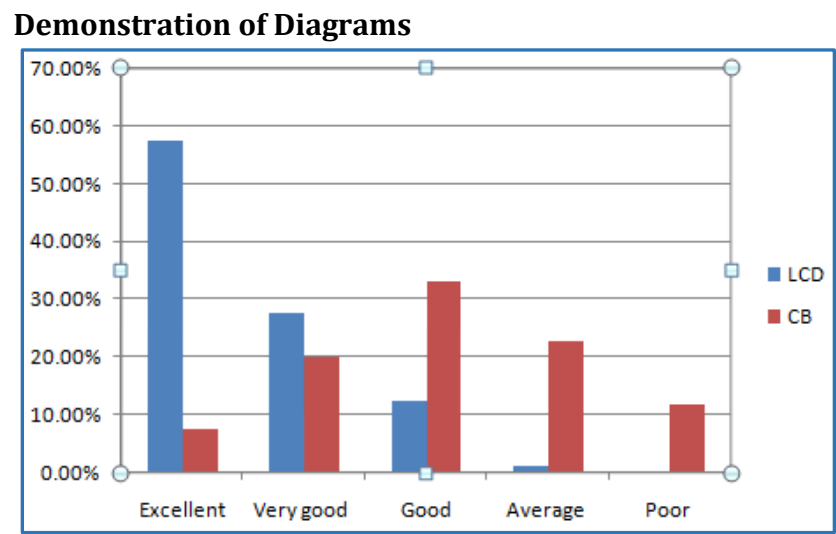

Bar Diagram 4

\begin{tabular}{|c|c|c|}
\hline Teaching Aid used & LCD & Chalkboard \\
\hline Excellent & $57.60 \%$ & $7.60 \%$ \\
\hline Very good & $27.70 \%$ & $20.10 \%$ \\
\hline Good & $12.50 \%$ & $33.30 \%$ \\
\hline Average & $1.30 \%$ & $22.90 \%$ \\
\hline Poor & $0 \%$ & $11.80 \%$ \\
\hline Table 5. Demonstration of Diagrams Percentage \\
Distribution of Feedback \\
\hline
\end{tabular}

\section{Demonstration of Charts}

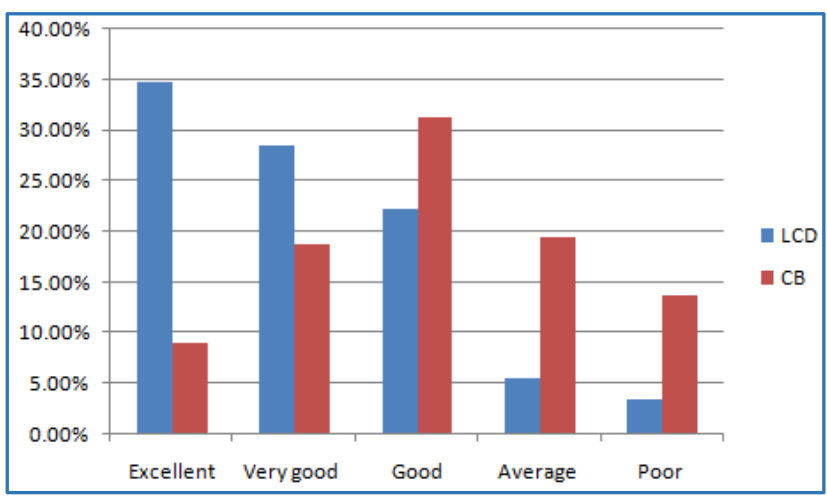

Bar Diagram 5

\begin{tabular}{|c|c|c|}
\hline Teaching Aid used & LCD & Chalkboard \\
\hline Excellent & $34.70 \%$ & $9.00 \%$ \\
\hline Very good & $28.50 \%$ & $18.80 \%$ \\
\hline Good & $22.20 \%$ & $31.30 \%$ \\
\hline Average & $5.50 \%$ & $19.40 \%$ \\
\hline Poor & $3.40 \%$ & $13.80 \%$ \\
\hline Table 6. Demonstration of Charts Percentage \\
Distribution of Feedback \\
\hline
\end{tabular}

Keeping eye Contact with Students

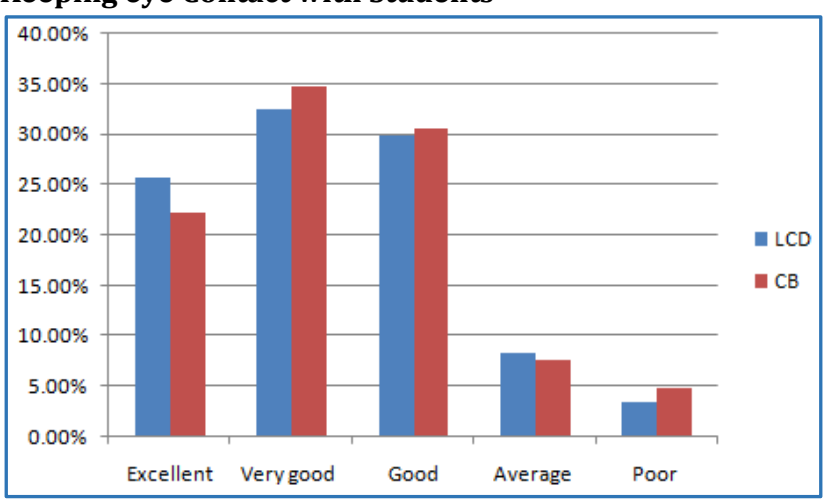

Bar Diagram 6

\begin{tabular}{|c|c|c|}
\hline Teaching Aid used & LCD & Chalkboard \\
\hline Excellent & $25.70 \%$ & $22.20 \%$ \\
\hline Very good & $32.60 \%$ & $34.70 \%$ \\
\hline Good & $29.90 \%$ & $30.60 \%$ \\
\hline Average & $8.30 \%$ & $7.60 \%$ \\
\hline Poor & $3.40 \%$ & $4.80 \%$ \\
\hline
\end{tabular}

Table 7. Keeping Eye Contact with Students Percentage Distribution of Feedback

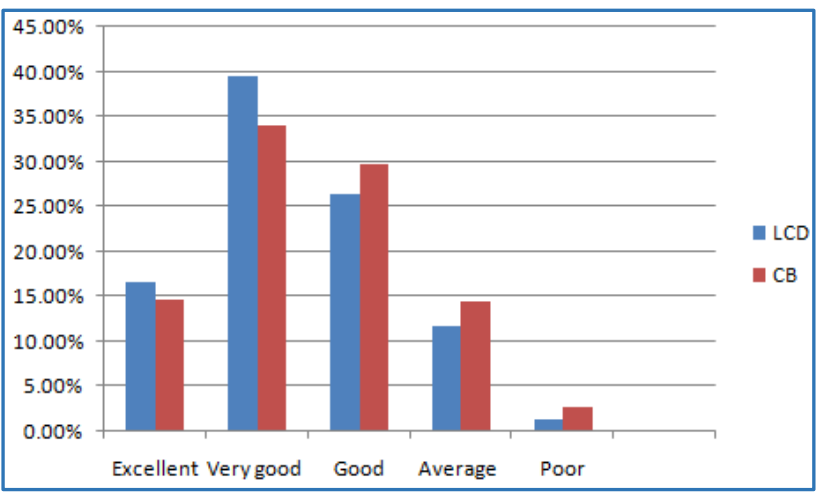

Bar Diagram 7

\begin{tabular}{|c|c|c|}
\hline Teaching Aid used & LCD & Chalkboard \\
\hline Excellent & $16.70 \%$ & $14.60 \%$ \\
\hline Very good & $39.60 \%$ & $34.00 \%$ \\
\hline Good & $26.40 \%$ & $29.70 \%$ \\
\hline Average & $11.80 \%$ & $14.50 \%$ \\
\hline Poor & $1.30 \%$ & $2.70 \%$ \\
\hline
\end{tabular}

Table 8. Conclusion- Percentage Distribution of Feedback

Overall Assessment of the Session

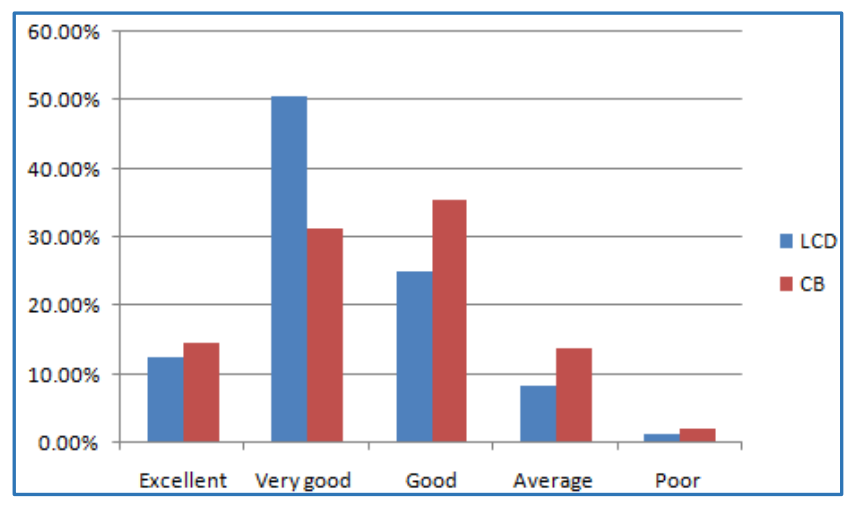

Bar Diagram 8

\begin{tabular}{|c|c|c|}
\hline Teaching Aid used & LCD & Chalkboard \\
\hline Excellent & $12.50 \%$ & $14.60 \%$ \\
\hline Very good & $50.70 \%$ & $31.30 \%$ \\
\hline Good & $25.00 \%$ & $35.40 \%$ \\
\hline Average & $8.30 \%$ & $13.80 \%$ \\
\hline Poor & $1.30 \%$ & $2.00 \%$ \\
\hline Table 9. Overall Assessment of the Session- Percentage \\
Distribution of Feedback \\
\hline
\end{tabular}

\section{DISCUSSION}

The study throws light on the effectiveness of teaching aids for a large class teaching method like the lecture. It also 
highlights the significance of using these teaching aids with discretion in the individual situation.

In the present day medical curriculum, the most commonly used teaching learning method used for large groups is definitely the classical lecture. In spite of its limitations, the advantages of the method, justifying its frequent usage include the time factor, coverage of vast topics in a limited period of time and the need for less faculty for addressing a large group.

In the present study, classes conducted with LCD as the only teaching aid were compared with classes conducted using chalkboard as the only teaching aid. Statistical analysis of the marks of MCQ tests conducted after the two sets of classes showed a significant difference with a higher value for classes which used LCD. This may be due a better understanding of the subject and more retention of the points in memory when the ideas were projected visually.

\section{Analysis of the Feedback from Students after each set of Classes Showed the following Details-}

- Introduction to the topic won better scores in classes using LCD compared to chalkboard.

- Understanding of subject matter showed similar scores with the two methods.

- Flow of subject matter scored slightly better in classes using LCD compared to chalkboard.

- According to students' rating, demonstration of diagrams was far better using the LCD projector compared to chalkboard.

- Demonstration of charts also won better scores for LCD projector than chalkboard.

- Students gave the feedback that eye contact was maintained to a more or less same extent in the two sets of classes.

- Conclusion part of the class was rated similarly in the two methods.

- The overall assessment of the two sets of classes showed similar results.

One of the major findings in the study is the feedback of students in favour of LCD for demonstration of diagrams and charts and also of an interesting introduction to the topic using a relevant picture or statement. Other features like understanding and flow of subject matter were unaffected by the teaching aid. Maintenance of eye contact, conclusion of the class and overall assessment of the sessions also showed similar scores. These findings again point to the fact that teaching aid only helps the teacher and cannot replace the teacher or the quality of subject presentation.

Since the study group was a large class of 183 students, various factors could have influenced the study including visibility for the back rows of students and the attention given to the lectures. In a smaller group, the observations may differ from the present study.

In the present study, measures were taken to avoid teacher bias, student bias and subject bias. More confirmative observations can only be made after further similar studies in different subjects and by different teachers and for different batches of students.
However, in each class the use of the two teaching aids for specific purposes depends on the discretion of the teacher and the skills of the teacher to use the instrument to the maximum benefit of the students.

\section{Implications of the study}

- Introduction of a topic can be well projected using a proper diagram or statement.

- Factors like understanding and flow of subject matter does not depend much on the teaching aid.

- Eye contact can be well maintained in class while using the LCD projector or chalkboard.

- Conclusion of a class does not vary depending on whether LCD projector or Chalkboard is used as a teaching aid.

- Overall subjective assessment of a class by students is not dependent on teaching aids.

In any teaching session, the use of proper aids for the maximum benefit of the learner is dependent on the teacher.

The teacher cannot be replaced by any other tool used as a teaching aid.

\section{CONCLUSION}

The conclusions of the present study include the following:

- The mean marks of students were better in a test conducted after classes using the LCD projector compared to the one conducted after classes using the chalkboard.

- Demonstration of diagrams and charts was better using the LCD projector.

- Introduction of a topic scored better with LCD projector.

- Understanding and flow of subject were rated similarly using the two methods.

- Eye contact, conclusion of the class and overall assessment of the session showed similar scores in the two groups.

\section{REFERENCES}

[1] Phuongthaospa. Chalkboard - the effective teaching aid. Journal for PELT 2013. https://peltjournal.wordpress.com/2013/10/02/chal kboard

[2] Tomlinson. Chalk as a teaching aid. 2013. www.studymode.com/essays/Chalk-As-a-TeachingAid-1940218. html10-06-2015.

[3] Brown A. The advantages of using chalkboard in teaching. How contributor www.ehow.com , Education > K-12 > K-12 for educators 03-2015.

[4] Davis BG. Tools for teaching. Chalkboard: advantage as and disadvantages of using LCD projectors. $2^{\text {nd }}$ edn. 2009:436-9, 453-5.

[5] Maixuyen N. Using chalkboard and teacher as teaching aids.

2013.

https://peltjournal.wordpress.com/2013/10/16/usin g-chalkboard-and Journal for PELT 2015.

[6] Ritzel. Chalkboard skills: how effective are you? ritzel.siu.edu/courses/443s/classroom/chalkboard.m 2015.

[7] Wong KT. The use of Liquid Crystal Display (LCD) panel as a teaching aid in medical lectures. Med Teach 1992;14(1):33-6. 


\section{Jemds.com}

[8] Ramaiah GK. Have modern teaching aids, such as PPT, Laptops, Smart Boards, LCD projectors etc. Really improved the class room teaching? www.researchgate.net 2015.

[9] Malter B. LCD projectors make chalkboards obsolete in high school computer lab. Posted on 09/01/1997 thejournal.com/.../LCD-projectors-make-chalkboardsobsolete-in 2014.
Original Research Article

[10] Borah RM. How to use modern teaching aids to make teaching more effective? Posted on $4^{\text {th }}$ November 2014. www.indiastudychannel.com〉 Resources > Education 2015. 